\title{
EDITORIAL
}

\section{Can Impact Factor data be trusted?}

\author{
Catherine M Ketcham and James M Crawford
}

Laboratory Investigation (2008) 88, 340-341; doi:10.1038/labinvest.2008.12; published online 25 February 2008

The opinions presented in this editorial are solely those of the authors and do not represent the Editorial Board of Laboratory Investigation, The United States and Canadian Academy of Pathology, or Nature Publishing Group. Department of Pathology, Immunology and Laboratory Medicine, University of Florida College of Medicine, Gainesville, FL, USA Correspondence should be addressed to: ketcham@pathology. ufl.edu ournal impact factors have a crucial role, either positive or negative, in establishing the status of a journal and the perceived importance of papers that these journals publish. Two recent editorials ${ }^{1,2}$ call into question the integrity of the data used by the Thomson Corporation to calculate impact factors. The author's concerns include the lack of verification of the primary data, apparent inconsistencies between official impact factors and the posted citation data, errors in the calculations of the total numbers of papers in journals and the categories in which they are placed, and Thomson's customer service. We are not able to offer any insight into verification of the data collection; however, we do wish to comment on the other issues.

First, we have used the Web of Science ${ }^{\circledR}$ on the ISI Web of Knowledge ${ }^{\text {SM }}$ site to verify the impact factor of our own journal, Lab Invest, and have found the citation data to be accurate. Second, the article count used for the calculation of the Lab Invest 2006 impact factor is correct. It was not correct in 2004, but was subsequently adjusted by Thomson at our request. Third, our experiences with the support staff at Thomson have always been satisfactory. In this report, we rigorously address the issue of consistency between the published impact factors and the raw citation data presented on the Thomson web site, and unlike Rosser et al, ${ }^{1,2}$ we describe here the way our searches were performed and also show our data.

Impact factors and the summaries of the data used in their calculations are presented in the Journal Citation Reports ${ }^{\circledR}$ section of the Thomson Web of Knowledge site. To verify the 2006 impact factor for a journal, one needs to confirm both the numerator (2006 citations to papers published in the journal in 2004 and 2005) and the denominator (the sum of eligible papers published in 2004 and 2005). The numerator can be calculated by careful examination of data from Cited Reference Searches on the Web of Science section of the Thomson web site. The denominator can be checked by performing a General Search on the same data, sorting the results by document type, comparing it to the journal's table of contents, and familiarizing oneself with the journal's content so as to verify classification of articles.

Table 1 shows the results of a crosscheck of the numerators (numbers of citations) for the 2006 impact factors of six journals. For five out of six journals analyzed, the apparent impact factors calculated from the Cited Reference Search are within $0.8 \%$ of the official values presented in the Journal Citation Reports. For the sixth journal, Thomson has been notified of the discrepancy and is conducting an investigation.

It is also possible to use the data on the Web of Science to calculate modified impact factors for journals of interest, such as impact factors excluding journal self-citations or review articles, ${ }^{3}$ both of which are helpful in journal evaluation. Because we found the data on the Web of Science to be reliable for the retrospective calculation of impact factors, we hypothesized that it could also be used for prediction of upcoming impact factors. Before the 2006 impact factors were released, we published predicted 2006 impact factors for six Pathology journals, based on the rate of accrual of citation data in real time. ${ }^{4}$ We are now able to report that the accuracy of these predictions was greater than $95 \%$ in 5 out of 6 cases (Table 2). These data are further evidence of the internal consistency, transparency and usefulness of the Web of Science data:

We therefore conclude that subscribers can use the Thomson ISI Web of Knowledge site with reasonable confidence. We concur that there are mechanisms by which journals, rightly or wrongly, can tilt calculated impact factors in their favor. However, blanket indictment of the data available for computation of impact factors seems to be inappropriate. 
Table 1 Calculations of journal impact factors (IF) from Thomson Web of Science data

\begin{tabular}{|c|c|c|c|c|c|c|c|}
\hline \multirow[t]{2}{*}{ Journal } & \multicolumn{2}{|c|}{$\begin{array}{l}\text { Calculated from cited } \\
\text { reference search }\end{array}$} & \multicolumn{2}{|c|}{$\begin{array}{l}\text { Official count from } \\
\text { journal citation reports }\end{array}$} & \multirow[t]{2}{*}{$\begin{array}{l}\text { Calculated } \\
2006 \mathrm{IF}^{\mathrm{b}}\end{array}$} & \multirow[t]{2}{*}{$\begin{array}{l}\text { Official } \\
2006 \text { IF }^{\mathrm{b}}\end{array}$} & \multirow[t]{2}{*}{$\begin{array}{l}\text { Calculated } 2006 \text { IF } \\
\text { as } \% \text { of official IF }\end{array}$} \\
\hline & $\begin{array}{l}2004 \text { citations } \\
\text { in } 2006\end{array}$ & $\begin{array}{l}2005 \text { citations } \\
\text { in } 2006\end{array}$ & $\begin{array}{l}2004 \text { citations } \\
\text { in } 2006\end{array}$ & $\begin{array}{l}2005 \text { citations } \\
\text { in } 2006\end{array}$ & & & \\
\hline Am J Pathol & 2786 & 1548 & 2814 & 1553 & 5.873 & 5.917 & 99.2 \\
\hline J Clin Invest & 5920 & 4936 & 5983 & 4966 & 15.620 & 15.754 & 99.2 \\
\hline J Exp Med & 4742 & 5013 & 4767 & 5010 & 14.452 & 14.484 & 99.8 \\
\hline J Pathol & 1138 & 893 & 1153 & 903 & 5.689 & 5.759 & 98.8 \\
\hline Lab Invest & 777 & 508 & 769 & 509 & 4.477 & 4.453 & $100.5^{c}$ \\
\hline Modern Pathol & 659 & 678 & 703 & 847 & 3.237 & 3.753 & 86.3 \\
\hline
\end{tabular}

Am J Pathol, American Journal of Pathology; J Clin Invest, Journal of Clinical Investigation; J Exp Med, Journal of Experimental Medicine; J Path, Journal of Pathology; Modern Pathol, Modern Pathology.

${ }^{a}$ Cited reference searches were performed in batches of 50 papers for Am J Pathol and J Clin Invest, and in batches of 10 papers for the remainder of the journals. Since a citing article is only listed once per search, regardless of how many papers in that search it cites, it is more accurate to search in small batches.

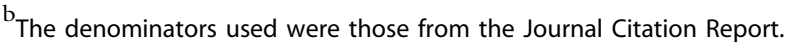

${ }^{c}$ Cited Reference Searches can exceed $100 \%$ of Journal Citation Report data if disallowed citations are found.

Table 2 Accuracy of impact factors predicted from data obtained from Thomson Web of Science*

\begin{tabular}{lccc} 
Journal & $\begin{array}{c}\text { Predicted } \\
2006 \\
\text { IF (from } \\
\text { Ref. 4) }\end{array}$ & $\begin{array}{c}\text { Official } \\
2006 \text { IF }\end{array}$ & $\begin{array}{c}\text { Predicted } \\
2006 \\
\text { IF as \% } \\
\text { Official IF }\end{array}$ \\
\hline Lab Invest & 4.396 & 4.453 & $98.7 \%$ \\
Modern Pathol & 3.485 & 3.753 & $92.9 \%$ \\
Am J Pathol & 5.665 & 5.917 & $95.7 \%$ \\
J Pathol & 5.612 & 5.759 & $97.4 \%$ \\
Am J Surg Pathol & 4.165 & 4.144 & $100.5 \%$ \\
Hum Pathol & 2.813 & 2.810 & $100.1 \%$
\end{tabular}

*Predictions were made December 31, 2006; the official 2006 impact factors were released June 19, 2007.
1. Rossner M, Van Epps H, Hill E. Show me the data. J Exp Med 2007;204:3052-3053.

2. Rossner M, Van Epps H, Hill E. Irreproducible results: a response to Thomson Scientific. J Cell Biol 2008;180: 254-255.

3. Ketcham CM, Crawford JM. The impact of review articles. Lab Invest 2007;87:1174-1185.

4. Ketcham CM. Predicting impact factor one year in advance. Lab Invest 2007;87:520-526. 